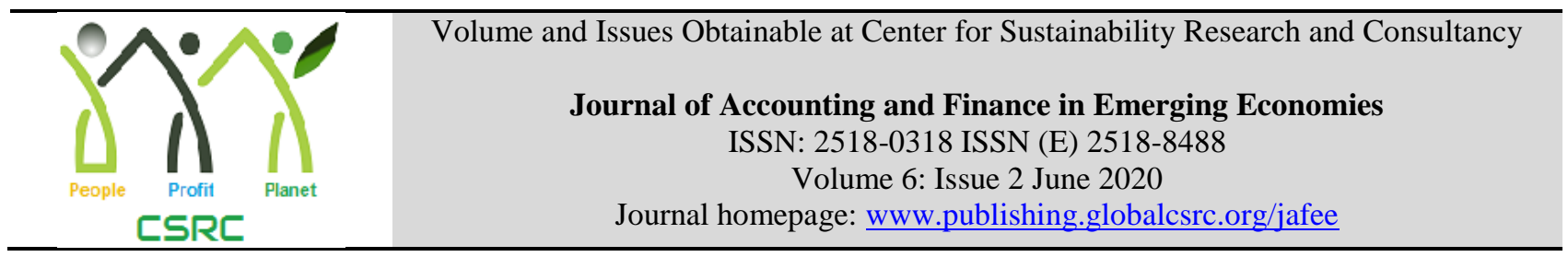

\title{
Good and Bad frames in the News Coverage of the Pakistan English Newspaper in the Regime of Pakistan Peoples Party from 2008 to 2013
}

\author{
${ }^{1}$ Salman Amin, ${ }^{2}$ Ghulam Shabir, ${ }^{3}$ Saqib Riaz \\ ${ }^{1}$ PhD Scholar, Allama Iqbal Open University Islamabad, Pakistan, salmanio2010@ hotmail.com \\ ${ }^{2}$ Faculty of Media and Communication Studies, University of Central Punjab, Lahore, Pakistan, \\ drshabair@outlook.com
}

${ }^{3}$ Hod, Department of Mass Communication, Allama Iqbal Open University, Islamabad, Pakistan, saqib_riaz@aiou.edu.pk

\begin{tabular}{l}
\hline ARTICLE DETAILS \\
\hline History \\
Revised format: May 2020 \\
Available Online: June 2020 \\
\\
\hline Keywords \\
General issue, Political Regime, \\
Newspapers, Content Analysis, \\
Democratic, Socioeconomic. \\
\hline
\end{tabular}

JEL Classification

M1, M14

\begin{abstract}
The study examined the coverage of general issues and to find out the performance of Pakistan Peoples Party from 2008 to 2013; through English Pakistani newspaper. The aim of this study to investigate the coverage of general issues that how the newspapers framed these issues in a "Good" and "Bad" frame. Furthermore, these frames were showing the credibility of the government. Quantitative content analysis method was used and, the population, all news stories related to general issues, published in selected newspapers, last five years in a selected Regime from 2008 to 2013 in Pakistan. The systematic Random sampling method was deemed appropriate and employed for this study. The finding of this study shows that The PPP government completed its five years term, in that tenure bad governance was in peak. Due to bad governance, poverty was on peak, and the worst model was adobe to control law and order situation, corruption was on peak, all type of terrorism practically active and had no proper plan to fulfil basic needs of the general public. There were waves of political unrest ahead of the 2008 and 2013 general election. Unfortunate incident happened in December 2007 assassination of Benazir Bhutto, the former prime minister and chair of the PPP, and there were several attacks in KP and FATA targeting leftist politicians and political rallies in the weeks preceding the 2008 general election.
\end{abstract}

\section{OPEN ACCESS}

(C) 2020 The authors, under a Creative Commons Attribution-NonCommercial 4.0

Corresponding author's email address: salmanio2010@ hotmail.com

Recommended citation: Amin, S., Shabir, G., Riaz S, M. (2020). Good and Bad frames in the News Coverage of the Pakistan English Newspaper in the Regime of Pakistan Peoples Party from 2008 to 2013: Journal of Accounting and Finance in Emerging Economies, 6(2), 357-365. 


\section{Introduction}

Governance is an extensive model with all its characteristics that includes the economics, regulatory role of government and law-making and its implementation. In Pakistan, corruption is just like a termite. It is beneficial for a private owner but not for public ownership. Such environment indicates poor governance. A good government should provide the basic need for the public, and implementation of fair policies for goods and services of the governance; Officials and Authorities (World Bank 1992). According to the Asian Development Bank, (1997) the core of governance is like an administrative or management; such administrative or management consists of accountability of public department, the fair implementation of the law and its development of information and transparency. The government based on the constitution, such a constitution which is exercised or followed by government (Husain, 2013).

Individuals 'cognizance of their existence, their community and culture, and the World greatly shaped by how media portrays news and events (Shoemaker, 1996). The choice of events that will incorporate in "news" and the way they will present to the public does not come about casually; rather, it is the result of cautious selection methods by media personnel which includes both the editors and the journalists. Executive policies of media groups and the opinions and beliefs of media personnel are the major factors that affect selection processes. "News content is the product or consequence of [journalistic] routines, practices, and values." (Riffe et al., 1998).

Newspapers tell the standing of an article by its strategic placement on a specific page, with its length and headline, quite. Media outlets and persons are usually the decision-makers who determine the order of news items in which they should be prioritized. It is the only type of media that identifies which news among the dozens of ongoing issues should be the prime issue' of the day. As the masses are dependent upon media for analysis, its role becomes very critical in rearranging and prioritizing the news. Therefore, media assert power and influence on the people reliant upon it. History shows that print media especially newspapers in Pakistan played a mature role and remained objective in their business; however; the contemporary race of commercialization has given birth to the wave of 'popular and crispy' styled news which is being manoeuvred by media outlets to increase their rating. (Saroshisar, 2016).

Another most obvious example of using this kind of media to set a specific agenda is that the mainstream political parties are trying to build public opinion on important national issues using this. An example of it was observed in the recent past where the civil and military establishment was trying to destabilize and topple down the government of the elected President Mr Zardari. It grasped the attention of, media and became a hot topic not only for media but also for politicians, and audiences. The expected military take over, and the importance of democracy for the country were given extensive coverage in newspapers' opinion pages and prime time talk shows. (Saroshisar, 2016).

\section{Problem Statement}

This study designed to investigate the coverage of general issues in the Pakistan Peoples Party's Regime (2008 to 2013) in the English Pakistani press. This study tries to investigate the episodic as well as the thematic frames used in the coverage of general issues in the selected newspapers. The study made use of frames regarding general issues in the English press of Pakistan because to find out how the press covered the issues and presented the government performance.

\section{Literature Review}

The level of good governance assesses this surge for improvement in the lifestyle of its citizens in the country. Pakistan can achieve the good governance by introducing integrity, coordination, cooperation among individuals as well as institutions, besides the economic sustainability and proper policy process implementation (Asghar, 2013). The research looks at some of the harsh realities of Pakistan and it's after affects that have occurred due to the evils of 
corruption in society. The WGI cover over 200 countries and territories, measuring six dimensions of governance starting in 1996: Voice and Accountability, Political Stability and Absence of Violence/Terrorism, Government Effectiveness, Regulatory Quality, Rule of Law, and Control of Corruption. The aggregate indicators are based on several hundred individual underlying variables, taken from a wide variety of existing data sources. The data reflect the views on governance of survey respondents and public, private, and NGO sector experts worldwide (Worldwide Governance Indicators, 2016). Pakistan, since its inception, has been showing its concern improving its human and institutional capacity which can help to improve the livelihoods of its citizens. It is the level of good governance that accesses the improvement in the lifestyle of citizens of a country. By introducing coordination, integrity and sense of cooperation among individuals and institutions, in addition to proper policy implementation and economic sustainability, the country can achieve good governance (Asghar, 2013).

The section "Way forward" looks at some recommendations by various researchers in the journey of Good Governance in Pakistan and includes suggestions by the author on possible solutions (Ahmed \&Basit, 2012). Ayoub\&Ahmed (2013) based on their analysis in two newspapers Dawn and The Nationidentifies the patterns in USA-Pakistan relations specifically with the reference of Waziristan drone strikes. It was evident from the results that the press of Pakistan have depicted the drone-based relations between the two countries negatively due to the double standard policy adopted by the USA. International media, on the other hand, has its agenda of framing of Islamic states and Islam as negative. (Yusof et al., 2013) research was focused on the problem of finding the framing methods of international media related to terrorism and Islam. His findings proved that those media groups labelled Islam as a terrorist religion. This continued even after Osama Bin Laden's death. Islam was associated with terrorism as a religion and was framed in a biased manner and negatively. Nelson (2009) pointed out that President Zardari confessed that militant groups were created and nurtured deliberately as a part of a policy aiming to achieve some short-term objectives. Zardari also said, Let us be truthful to ourselves and make a candid admission of the realities. The terrorists of today were the heroes of yesteryears until 9/11 occurred and they began to haunt us as well. Shah and Bilal (2015), analyzed the editorials of the daily Nation and Dawn and examined the roles of newspapers to construct ideology of the right and left-wing. Main focus of their studies was on editorials of PNS Mehran base attack and Osama Bin Laden's death episode. They used selected editorials and analytical devices which include syntactic structures, word choices, and rhetorical structures, local and global semantics were examined. Results proved that editorials did not present issues and problems in an impartial way.

Haarhuis and Leeuw (2004) analyses the anticorruption World Bank programme and examines their efficiency rate. These programs include the two approaches, namely the bottom-up and the top-down approaches. Petty corruption is related to import-export permits, annual tax payments, loan applications, public utilities, public contracts, judicial decisions and laws and policies. Grand corruption connected to bureaucratic red tapping, public trust in politicians and political donations (NAB,2007). Amin et al. (2010) investigated that household economic status, as indicated by wealth index; act as an important determinant that affects the behaviour of healthcare. Well-off households' mothers were significantly more inclined towards utilizing modern institutional delivery, trained antenatal care, and postnatal care as compared to those belonging to poorest economic class. In Pakistan, the state of health reveals that the country currently lags behind others in contraceptive use, immunization coverage, and child and infant mortality rates. In terms of primary \& tertiary services of health, the rural poor are at a greater disadvantage, and they never benefited from public healthcare services in real sense. Due to diminished and poor role of public healthcare services, more space is available for private health facilities, and thus their condition has enormously improved (Afzal and Yusuf, 2013). Unfortunately, these policies could not get a place in five-year development plans and the Five-year plan and period of education policies remained quite different from each other. All these lacunas resulted in slow-down of education progress speed. So the targets of plans and policies, made related to education are never fully achieved up till now (Irfan, 1995). According to Nazet.al ., (2014)The law enforcement mechanisms including policing in Pakistan is particularly perceived to be the most corrupt and ineffective system that has created hurdles 
for the breakdown of law and order situation in the country.

Ali, Hashmi and Hassan (2013) examined economic and political both the factors and attempted to identify and predict the low investment reasons and causes of unstable economic growth in the country. The study highlighted that factors other than the economic ones including political instability, corruption, repeated regime changes, political conflicts among parties and institutions and energy crisis had been the main cause of lower investment and poor economy. These factors create uncertainty and thus make the investment making, risky in the country. Frames are not just useful to readers and viewers, but to news organizations as well. News organizations shape their reports to elicit favourable reactions from readers and viewers, and the anticipated reactions of the public also affect the rhetoric and actions of political elites, who are the primary 'sponsors' of news frames (Gamson, 1989). For example, linking news text to the rhetoric of the Reagan administration, Entman (1991) found the frame used supported the administration's positions. Framing has related to collective action (See Gamson; Klandermans; Snow and Benford in Frontiers in Social Movement Theory) in that certain frames often motivate individuals to action. For example, characterizing a government action as unjust or immoral as in the US bombing of Cambodia, moved many Americans to protest in the late 1960s. The frame itself does not motivate individual ${ }^{\wedge}$ to action, but blame must be specified for action to take place (Snow and Benford, 1992).

\section{Methodology}

The investigator applied quantitative content analysis. This method adopted to explore the picture on the basis of contents. For this purpose of this study, the researcher examined the issues and to evaluate the performances of PPP (2008 to 2013). The population for this studywere, all news stories were related to general issues, published in daily Dawn, The News, The Nation, and Daily Times from 2008 to 2013. The news stories were retrieved from the Lexis-Nexis electronic database by using various terminologies related to general issues of the public. A systematic Random sampling method deemed appropriate and employed for this study. According to Krippendorff (1980), The systematic random sampling favoured when data enumerated in all included and excluded in a sampling unit for analysis. The data was analyzed through AMOS to ensure objectivity in the results.

\section{Findings}

In this study try to accumulate different issues which are the core exploration on this study, which include: Terrorism, Corruption, Health, Education, Law and Order and Others (belongs to three tiers of governments).

Many issues were discussed in with relevant references and resources but now also discuss the micro issue which leads to macro issue for example; Terrorism category divided into five sections i.e., StateSponsored terrorism, Dissent terrorism, Terrorists and the Left and Right, Religious terrorism and Criminal Terrorism. So, in this study try to accumulate different issues which are the core exploration on this study, which include: Terrorism, Corruption, Health, Education, Law and Order and Others (belongs to three tiers of governments). The news related to issues and sub-issues published in selected newspaper( The Dawn, The News, The Nation and Daily Times) from 2008 to 2007 in Political Regime of PPP. The Table 1.1 shows that the terrorism leads to State-Sponsored terrorism(4.56\%), Dissent terrorism(5.85\%), Terrorists and the Left and Right(5.82\%), Religious terrorism(5.45\%) and Criminal Terrorism(7.30\%). The corruption issue i.e., Bribery(3.38\%), Graft(4.29\%), Extortion(4.16\%), Kickback(3.54\%), Cronyism(2.86\%) and Embezzlement(2.47\%). The Health issue and its categories are: Malaria(2.28\%), Tuberculosis(3.13\%), Dengue Fever(4.59\%), Cancer(1.58\%), Diabetes(1.76\%) and HIV/AIDS(1.24\%). The Education: Women's Education(1.19\%), Curriculum(1.09\%), Child Labour(2.18\%), Less training institutions(1.57\%), Corruption in education(4.21\%), Gender discrimination(1.15\%), Allocation of funds(3.13\%) and Less research work(0.83\%). The Law and Order situation; Murder(3.89\%), Assault on Public Servants(2.29\%), Zina(1.82\%), Kidnapping/Abduction(3.98\%), Suicide(1.40\%), Dacoity(2.81\%) and Motor Vehicle 
Theft/Snatching(3.34\%). And Others issue;Political Instability(4.05\%) and Political Victimization $(2.84 \%)$

Table 1.1 Overall Coverage General Issues in Selected Newspapers from 2008 to 2013

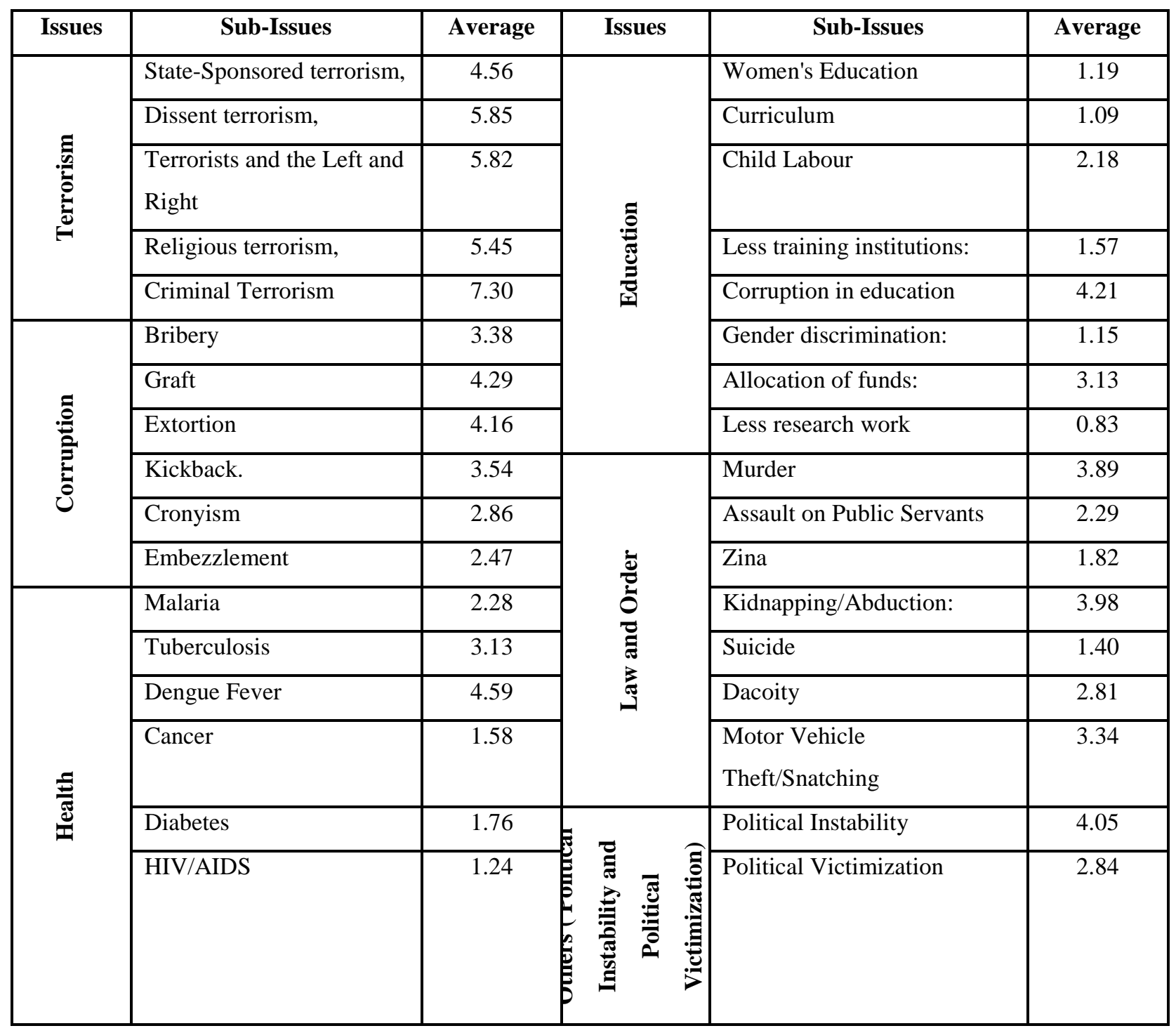

Table 1.3. Framing of News Stories in Newspapers During 2008 to 2013

\begin{tabular}{|l|c|l|c|c|c|c|c|c|}
\hline & \multicolumn{2}{|c|}{ The Dawn } & \multicolumn{2}{c|}{ The News } & \multicolumn{2}{c|}{ The Nation } & \multicolumn{2}{c|}{ Daily Time } \\
\hline Issue & $\begin{array}{l}\text { Good- } \\
\text { Gover. }\end{array}$ & $\begin{array}{l}\text { Bad } \\
\text { Gover. }\end{array}$ & $\begin{array}{l}\text { Good- } \\
\text { Gover. }\end{array}$ & $\begin{array}{l}\text { Bad } \\
\text { Gover. }\end{array}$ & $\begin{array}{l}\text { Good- } \\
\text { Gover. }\end{array}$ & $\begin{array}{l}\text { Bad } \\
\text { Gover. }\end{array}$ & $\begin{array}{l}\text { Good- } \\
\text { Gover. }\end{array}$ & $\begin{array}{l}\text { Bad } \\
\text { Gover. }\end{array}$ \\
\hline Terrorism & 1826 & 3544 & 2146 & 3219 & 1833 & 3557 & 2490 & 1526 \\
\hline Corruption & 1114 & 2162 & 1316 & 1975 & 1112 & 2160 & 1532 & 939 \\
\hline Health & 753 & 1461 & 879 & 1319 & 797 & 1547 & 985 & 604 \\
\hline Education & 842 & 1634 & 976 & 1463 & 845 & 1640 & 1092 & 669 \\
\hline Law and Order & 1078 & 2094 & 1265 & 1897 & 1093 & 2123 & 1465 & 898 \\
\hline Other & 368 & 713 & 412 & 617 & 399 & 774 & 438 & 269 \\
\hline
\end{tabular}


During Political Regime PPP (2008 to 2013) the framing of news about the general issue, in Table 1.3 The Dawn published the 1826 news regarding terrorism as good or controlled, and 3544 published the news as bad or negative. The news published 2146 news as good or controlled and 3219 as bad or negative response of governance. The Nation published the 1833 news as good or controlled and 3557 as bad or negative. Daily Times published the 2490 news as good performance or controlled and 1526 as bad performance or negative response. A further main issues in Pakistan is Corruption in table 1.3 the number of cases which were registered in Political Regime PPP (2008 to 2013). The Dawn published the 1114 news as good and 2162 as bad performance in 2008 to 2013. The news published the news on the same issue (Corruption) is 1316 as a good and 1975 news are published as bad performance or fail to control the corruption. The Nation published the 1112 news as good performance and controlled and 2160 news as a bad performance and uncontrolled. And last Daily Times published the news 1532 as a good and 939 as bad or negative. Third issue in table $\mathbf{1 . 3}$ is health which shows different figures in times span (2008 to 2013). A healthy Nation is not only valued in its own right, but it also raises the human capital of a country thereby contributing to the economic and social development. The Dawn newspaper published the 753 news as good or controlled and 1461 as bad or uncontrolled on health issue. The News newspaper published the 879 as good or controlled and 1319 as bad or uncontrolled.The Nation newspaper published the 797 as good or controlled and 1547 as bad or uncontrolled. Daily Time newspaper published the 985 as good or controlled and 604 as bad or uncontrolled. The fourth issue is education, in Table 1.3 The Dawn published the 842 news regarding education as good or controlled, and 1634 published the news as bad or uncontrolled. The news published the 976 news as good or controlled and 1483 as bad or uncontrolled response of governance. The Nation published the 845 news as good or controlled and 1640 as bad or uncontrolled. Daily Times published the 1092 news as good performance or controlled and 669 as bad performance or uncontrolled response. A main supplementary issue is Law and Order situation in Pakistan show in table 1.3 discussed in Political Regime PPP (2008 to 2013) by selected newspaper of the current study. The Dawn published the 1078 news as good and 2094 as bad performance in 2008 to 2013. The news published the news on the same issue (Law and Order) is 1265 as a good and 1093 news are published as bad performance or fail to control the Law or order situation. The Nation published the 2123 news as good performance and controlled and 2123 news as a bad performance and uncontrolled. Moreover, last Daily Times published the news 1465 as a good and 898 as bad or controlled. The political instability and political victimization is a part of every government. In table 1.3, The Dawn newspaper published the 368 news as good or controlled and 713 as bad or uncontrolled on other issues. The News newspaper published the 412 as good and 617 as bad. The Nation published the 399 as good and 774 as bad. Daily Time newspaper published the 438 as good and 269 as bad.

\section{Statistical Analysis}

The Structural Estimate Method(SEM) this technique which is run on AMOS to analyses and identify the correlation and effect among on the variable which was used in the study. Graphic 1.1 provides the analysis of path analysis in which correlation specify the estimate $(\beta)$ at the significance level, i.e., Pvalue $(-1 \quad 0+1)$. Furthermore, the result SEM reflected the acceptance and not supported of the hypothesis. In the current study the general issues and Selected Newspapers intensity have been taken as independent variables, And, Political Parties (PML-Q, PPP and PML-N) spending has taken as dependent and has been taken as mediating variable. The empirical results show that the correlation related to Issues in Political Regimes (PPP) from 2008 from 2013 by the selected newspaper i.e., "The Dawn", "The News", "The Nation and "Daily Times". This result indicated that the overall performance of government (PPP) is good and bad performance to control overall issues in Pakistan during his Regime. In table 4.4.1 illustrated that the terrorism is (-.23) Corruption (-.11), Education (-.21), Health (.19), Law and Order Situation (-.11) and Others issue (.13). Thus, it can understand that correlation between issues and political parties have direct relations and its consumption by the Sleeted Newspaper after introduction materialism in the model. The SEM and Model comparison shows that performance comparison of different issues through the newspaper in selected Regime. 


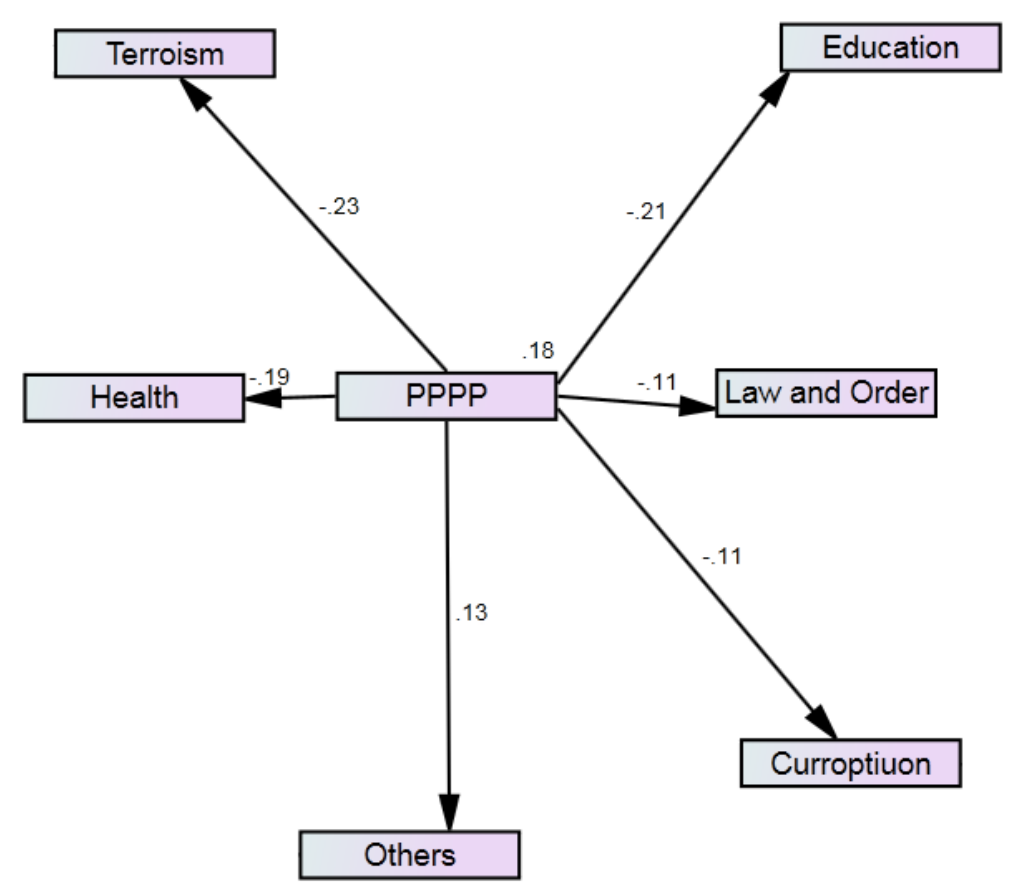

Graphic 1.1 SEM Model of Comparison related to Issues in Political Regimes (PPP) from 2008 from 2013

\begin{tabular}{|l|l|l|l|l|l|l|l|}
\hline \multirow{2}{*}{ Model } & \multirow{2}{*}{ DF } & \multirow{2}{*}{ CMIN } & \multirow{2}{*}{$\mathbf{P}$} & NFI & IFI & RFI & TLI \\
\cline { 5 - 8 } & & Delta-1 & Delta-2 & rho-1 & rho2 \\
\hline PPP & 1 & 0.016 & 0.898 & 0 & 0 & -0.074 & -0.103 \\
\hline
\end{tabular}

The overall coverage and significant difference between value of chi-square regarding general issues of the study in selected newspapers are (Chi-Square $=2.421$; P-Value $=0.946$ to the "Terrorism", ChiSquare $=3.610 ; \mathrm{P}-$ Value $=0.856$ the "Corruption", Chi-Square $=4.242 ; \mathrm{P}-$ Value $=0.467$ to the "Health", Chi-Square $=6.865 ; \mathrm{P}-$ Value $=1.322$ to the "Education", Chi-Square $=8.007 ; \mathrm{P}-$ Value $=0.073$ to the "Law and Order", Chi-Square $=12.681 ; \mathrm{P}$-Value $=0.013$ to the "Others).

\begin{tabular}{|l|l|l|}
\hline Pearson Chi-Square & Value & Asymp. Sig. (2-sided) \\
\hline Terrorism & $2.421^{\mathrm{a}}$ & .946 \\
\hline Corruption & $3.610^{\mathrm{a}}$ & .856 \\
\hline Health & $4.242^{\mathrm{a}}$ & .467 \\
\hline Education & $6.865^{\mathrm{a}}$ & .021 \\
\hline Law and Order & $8.007^{\mathrm{a}}$ & .091 \\
\hline Other & $12.681^{\mathrm{a}}$ & .013 \\
\hline
\end{tabular}




\section{Conclusion}

This study planned to examine the situation of the general issue in Pakistan. According to Kaufman and kaary (1996) presented the World Governance Indicator (Voice and Accountability, Political Stability and Absence of Violence, Government Effectiveness, Regulatory Quality, Rule of Law and Control of Corruption), Which means that a government is checked by or analyzed by these world indicators and theses indicators related to general issues, i.e., Terrorism, Corruption, Health, Education, Law and Order situation and Other (Political Instability and Victimization).

In the beginning of the twenty-first century, Pakistan faced the worst scenario with multiple issues. The Regime of PPP (Pakistan People Party Parliamentarian) is the first democratic Regime in the history of Pakistan in a true sense, both Prime Minister and President elected through proper electoral system. PPP government have no idea how to control over and gave better policy to tackles the general issues, especially for terrorism, corruption and law and order situation. Such issues which led to national issue the PPP government have a plan of action to control these issues. Moreover, PPP was not serious about providing the basic health and education facilities to the general public all over Pakistan and also interior Sindh as well as if concluded the other government like PML-N government from 2008 to 2013 at same in Punjab, the performance to control the general issue is quite good than the PPP government.

The finding of the study showed that terrorist attacks killed not only soldiers, civilians and religious and political identities but also the economic growth of Pakistan. These attacks hit all over Pakistan, especially on a large scale, and effects the main cities including Lahore, Peshawar, Rawalpindi, Multan, Karachi, Hyderabad and Quetta. In PPP Regime from 2008 to 2013 the Pakistan faced all type of terrorist attacked such as sponsored terrorism, cyber terrorism, religious terrorism, sectarian terrorism, left-wing and right-wing terrorism. Furthermore, it was in line with Nelson (2009) pointed out that President Zardari confessed that militant groups created and nurtured deliberately as a part of a policy aiming to achieve some short-term objectives. Zardari also said, Let us be truthful to ourselves and make a candid admission of the realities. The terrorists of today were the heroes of yesteryears until 9/11 occurred and they began to haunt us as well.

In this study, the structure and functioning of the elected government discussed to assess the political institutionalization in the in-terms of political institutionalization and the socioeconomic development was not a priority of government opposition parties hindered democracy by engaging it in adversarial political in traditional political style. Political Parties not seem serious to become a creditable to the ruling party and continued to hold the government responsible for every failure of democratic norms and procedure continued throughout the period contest PPP for political power their tactical at times threaten to derail the fragile democracy of Pakistan. However, the democratic government failed to deliver their promises whom they made before the election in terms of to tackles the issues, i.e., terrorism, corruption, health, education, and other issues.

\section{References}

Afzal, U. and Yusuf, A. (2013). The State of Health in Pakistan: An Overview. The Lahore Journal of Economics, 18: 233-247

Ahmed, A.N., \& Basit, A. (2012). Good Governance in Pakistan: Problems and Possible Solutions

Ali, S. H., Hashmi, S. H., \& Hassan, A. (2013). Relationship between political instability and domestic private investment in Pakistan: A time series analysis (1972-2009). Pakistan Business Review, $15(1), 1-26$.

Amin, R., Shah, N. and Becker, S. (2010). Socioeconomic Factors Differentiating Maternal 
and Child Health-Seeking Behavior in Rural Bangladesh: A Cross-Sectional Analysis. International Journal for Equity in Health, 9(9).

Asghar. UM.(2013), Governance Issues in Pakistan: Suggested Action Strategy, Research and Analysis (ISSRA), National Defence University, Islamabad.

Ayoub, U., \& Ahmed, T. (2013). Portrayal of Pakistan-US relationship regarding drone strikes on Waziristan in the editorials of Dawn and Nation: a comparative study. Academic Research International, 4 (6), 56-64.

Entman, R.M. (1991). Framing US Coverage of International News: Contrasts in Narratives of the KAL and Iran Air Incidents. Journal of Communication. 41 No. 4. 6-27.

Gamson, W. A., \& Modigliani, A. (1989). Media Discourse and Public Opinion on Nuclear Power: A Constructionist Approach. American Journal of Sociology 951 1-37.

Haarhuis. C. M and Leeuw, FL (2004). Fighting governmental corruption: the new World Bank programme evaluated. Journal of international development 16: 547-561

Hussain, F. (2013). Corruption In The Public Organizations Of Pakistan: Perceptual Views Of University Students. The Journal of Commerce, Vol. 4, No. 1 ISSN: 2218-8118, 2220-6043 Hailey College of Commerce, University of the Punjab, PAKISTAN. http://joc.hcc.edu.pk/articlepdf/joc201262_62_71.pdf

Krippendorff, K. (1980). Content analysis an introduction to its Methodology. London: Sage

Nelson, D. (2009). Pakistani president Asif Zardari admits creating terrorist groups.

The Telegraph.

Riffe, D., Lacy, S., \& Fico, F. (1998). Analyzing media messages: Using quantitative content analysis in research. Mahwah, NJ: Erlbaum.

Saroshisar. (2016). Role Of Media In Agenda Setting In Pakistan, REVOEVOREF

Socio-politico-economic Reform and Evolution will pave the path toward Revolution https://revoevoref.wordpress.com/2016/02/29/role-of-media-in-agenda-setting-in- Pakistan/ Shah, A, and Bilal. A. (2015). "Pakistan in 2014: Democracy under the Military's Shadow." Asian Survey 55(1):48-59

Snow, D. A, \& Benford, R.D.(1992). Master Frames and Cycles of Protest, in Frontiers in Social Movement Theory. Aldon D. Morris and Carol McClurg Mueller (eds).New Haven: Yale University Press.

Yousaf, M. Ihsan, F. Ellahi, A. (2015). Exploring the impact of good governance on citizens' trust in Pakistan, Fatima Jinnah Women University, Pakistan, Government Information Quarterly journal homepage: www.elsevier.com/locate/govinf, , http://dx.doi.org/10.1016/j.giq.2015.06.001 